\title{
Pendampingan Pembuatan Bahan Ajar Berbasis Multimedia Menggunakan Macromedia Flash Bagi Para Guru SD IT Salsabila Al Muthi'in, Yogyakarta
}

\author{
Dwi Nugraheny ${ }^{1)}$, Hero Wintolo ${ }^{2)}$, Anggraini Kusumaningrum ${ }^{3)}$, Sudaryanto ${ }^{4)}$ \\ Program Studi Teknik Informatika \\ Sekolah Tinggi Teknologi Adisutjipto, Yogyakarta \\ Jl. Raya Janti Blok R Lanud Adisutjipto, Yogyakarta \\ ${ }^{1)}$ henynug@stta.ac.id, ${ }^{2)}$ herowintolo@stta.ac.id, ${ }^{3)}$ anggraini@stta.ac.id, \\ ${ }^{4)}$ sudaryanto@stta.ac.id
}

\begin{abstract}
Teachers are a very noble profession, because one of the teachers task is to help in the intellectual life of the nation. As teachers in their daily life to educate the nation, requires the support of equipment that can be used in the teaching and learning process in the field that he has. Supporting equipment required can be hardware and software that can be utilized to compile teaching materials that are interesting for the students, one of them is multimediabased teaching materials. As a lecturer in the field of informatics, we are motivated to assist teachers especially teachers in SD IT Salsabila Al Muthi'in, Yogyakarta by doing the process of mentoring in the making of multimedia-based teaching materials using Macromedia Flash.
\end{abstract}

Keywords : Macromedia Flash, multimedia, pendampingan

\begin{abstract}
Abstrak
Guru merupakan profesi yang sangat mulia, karena salah satu tugas guru yaitu membantu dalam mencerdaskan kehidupan bangsa. Sebagai guru dalam kesehariannya untuk mencerdaskan kehidupan bangsa, membutuhkan adanya peralatan penunjang yang dapat digunakan dalam proses belajar mengajar di bidang yang diampunya. Peralatan penunjang yang dibutuhkan dapat berupa perangkat keras dan perangkat lunak yang dapat dimanfaatkan untuk menyusun bahan ajar yang menarik bagi perserta didiknya, salah satunya bahan ajar yang berbasis multimedia. Sebagai dosen yang berada dalam bidang informatika, kami tergerak untuk membantu guru-guru khususnya para guru di SD IT Salsabila Al Muthi'in, Yogyakarta dengan melakukan proses pendampingan dalam pembuatan bahan ajar berbasis multimedia menggunakan Macromedia Flash.
\end{abstract}

Kata Kunci : Macromedia Flash, multimedia, pendampingan

\section{Latar Belakang Masalah}

Proses pembelajaran merupakan rangkaian beberapa sistem yang saling berkaitan satu sama lainnya. Apabila salah satu sistem tidak dapat berfungsi maka sistem tidak dapat bekerja secara optimal. Proses pembelajaran akan lebih optimal jika dapat memanfaatkan media yang ada di sekitar kita. Penggunaan media dalam proses pembelajaran diharapkan dapat membantu guru agar lebih mudah dalam mengajarkan materi kepada para siswa. 
Pembelajaran yang dilakukan selama ini cenderung kurang memanfaatkan media pembelajaran yang ada. Beberapa hal yang menyebabkan hal ini terjadi adalah masih adanya pandangan dari guru bahwa media pembelajaran merupakan sarana yang mahal dan sulit dibuat sendiri oleh guru.

Salah satu media yang sering digunakan dalam proses pembelajaran di sekolah adalah media LKS (Lembar Kerja Siswa) dan diktat / modul pembelajaran. Oleh karena para guru pada umumnya memanfaatkan LKS atau diktat / modul pembelajaran yang diperoleh dari penerbit (bukan dibuat sendiri oleh guru) sehingga berakibat materi yang diberikan dalam LKS atau modul tersebut kurang sesuai dengan materi yang akan diajarkan oleh guru.

Kondisi di atas terjadi karena guru pada umumnya merasa kesulitan dalam mengembangkan media tersebut. Kemampuan guru dalam mengembangkan bahan ajar / diktat masih sangat rendah. Terdapat beberapa faktor yang menyebabkan hal ini terjadi, salah satunya masih minimnya penyelenggaraan pelatihan tentang pembuatan/pengembangan bahan ajar / diktat oleh instansi yang terkait.

Peralihan kurikulum KBK ke kurikulum yang baru menuntut adanya kemampuan guru untuk dapat membuat dan mengembangkan sendiri bahan ajar maupun media yang sesuai dengan tingkat kompetensi yang ada di masing-masing sekolah. Pengembangan bahan ajar akan optimal jika pembuat (pengembang) bahan ajar benar-benar mengetahui kondisi siswa yang akan menggunakan bahan ajar tersebut. Apabila kondisi ini dapat tercapai diharapkan siswa maupun guru akan lebih mudah berkolaborasi dalam mempelajari materi. Adanya kemampuan guru dalam mengembangkan bahan ajar secara tidak langsung akan meningkatkan life skill guru.

Oleh karena itu sangat penting untuk diselenggarakan kegiatan pengabdian pendampingan pembuatan bahan ajar berbasis multimedia menggunakan Macromedia Flash. Selain karena adanya permintaan guru untuk diberikan bekal dalam memulai mengembangkan bahan ajar, juga karena keinginan untuk membantu para guru dalam mengembangkan bahan ajar. Kegiatan pengabdian ini berupa pendampingan dalam pembuatan bahan ajar berbasis multimedia menggunakan Macromedia Flash yang memberikan media pembelajaran berefek animasi sehingga dapat menarik minat siswa untuk memahami materi yang diajarkan lebih antusias lagi.

Macromedia Flash adalah sebuah program yang ditujukan kepada para desainer maupun programer yang bermaksud merancang animasi untuk pembuatan halaman web, presentasi untuk tujuan bisnis maupun proses pembelajaran hingga pembuatan game interaktif serta tujuan-tujuan lain yang lebih spesifik (Dhany Yudhiantoro, 2006).

\section{Metode Pelaksanaan Pengabdian} yaitu :

Metode Pelaksanaan Pengabdian pada Masyarakat ini meliputi beberapa komponen

a. Sumber Daya Manusia (SDM)

Metode yang dipilih untuk memenuhi kebutuhan SDM dengan melakukan pendataan terhadap guru guru SD Salsabila Al Muthi'in yang kurang mampu atau masih kesulitan dalam membuat bahan ajar berbasis multimedia menggunakan perangkat lunak Macromedia Flash 


\section{b. Proses}

Melakukan penyusunan modul tentang membuat bahan ajar menggunakan Macromedia Flash. Kemudian melakukan sosialisasi dan pendampingan kepada guru-guru terkait dengan penyusunan bahan ajar menggunakan Macromedia Flash selama beberapa hari. Adapun proses pelaksanaan pendampingan dilakukan selama 2 (dua) hari pada tanggal 20 dan 21 Desember 2017, di laboratorium Sekolah Tinggi Teknologi Adisutjipto Yogyakarta,

\section{c. Produk}

Menghasikan guru yang mampu menyusun bahan ajar sehingga menarik minat peserta didik dalam mengikuti pelajaran.

d. Manajemen

Setelah melakukan sosialisasi, dilanjutkan dengan memberikan pendampingan guru untuk dilatih dalam menggunakan perangkat lunak Macromedia Flash tersebut hingga menguasai dengan baik.

\section{Hasil dan Pembahasan}

Hasil luaran yang dicapai dari kegiatan pengabdian kepada masyarakat antara lain:

1. Adanya bahan ajar berbasis multimedia, berupa modul bahan ajar berbasis multimedia untuk guru-guru SD Salsabila Al Muthi'in. Modul bahan ajar dibuat sejumlah guru-guru yang mengikuti pelatihan.

Adapun jumlah guru-guru SD Salsabila Al-Muthi'in yang mengikuti pendampingan sejumlah 19 guru, daftar hadir seperti terlampir pada tabel 1.

Tabel 1 Penguasaan Guru Terhadap Materi Macromedia Flash

\begin{tabular}{|c|l|c|c|}
\hline No & \multicolumn{1}{|c|}{ Nama Guru } & Frame & Motion \\
\hline 1 & Kamidah, S.Pd. & $\checkmark$ & $\checkmark$ \\
\hline 2 & Nina Andika, S.E. & $\checkmark$ & $\checkmark$ \\
\hline 3 & Endah Wienda Asmara, S.Pd. & $\checkmark$ & $\checkmark$ \\
\hline 4 & A. Budiyanto, S.Pd. & $\checkmark$ & $\checkmark$ \\
\hline 5 & Siti Nurhayati, S.Kom. & $\checkmark$ & $\checkmark$ \\
\hline 6 & Almas Iszati Zulfah & $\checkmark$ & $\checkmark$ \\
\hline 7 & Purwoko, S.Pd. & $\checkmark$ & $\checkmark$ \\
\hline 8 & Rahmadal Agus Mujiyanto, S.Pd. & $\checkmark$ & $\checkmark$ \\
\hline 9 & Imam Sofyan, S. Pd. I. & $\checkmark$ & $\checkmark$ \\
\hline 10 & Ranti Rifa'atul M., S.Pd. & $\checkmark$ & $\checkmark$ \\
\hline 11 & Garnisanti, S.Pd. & $\checkmark$ & $\checkmark$ \\
\hline 12 & Catur Rakhmawati, S.Sos. & $\checkmark$ & $\checkmark$ \\
\hline 13 & Rinda Tungga Dewi, S.E. & $\checkmark$ & $\checkmark$ \\
\hline 14 & Mahmudah, S.Pd. & $\checkmark$ & $\checkmark$ \\
\hline 15 & Umi Ismiyati, S.Pd. & $\checkmark$ & $\checkmark$ \\
\hline 16 & Uswatun Hasanah, S.Pd. & $\checkmark$ & $\checkmark$ \\
\hline 17 & Wardah Rohmatul A. & $\checkmark$ & $\checkmark$ \\
\hline 18 & Sri Budiarti, S.Pd. I. & $\checkmark$ & $\checkmark$ \\
\hline 19 & Yunianti, S.Pd. I. & & $\checkmark$ \\
\hline
\end{tabular}




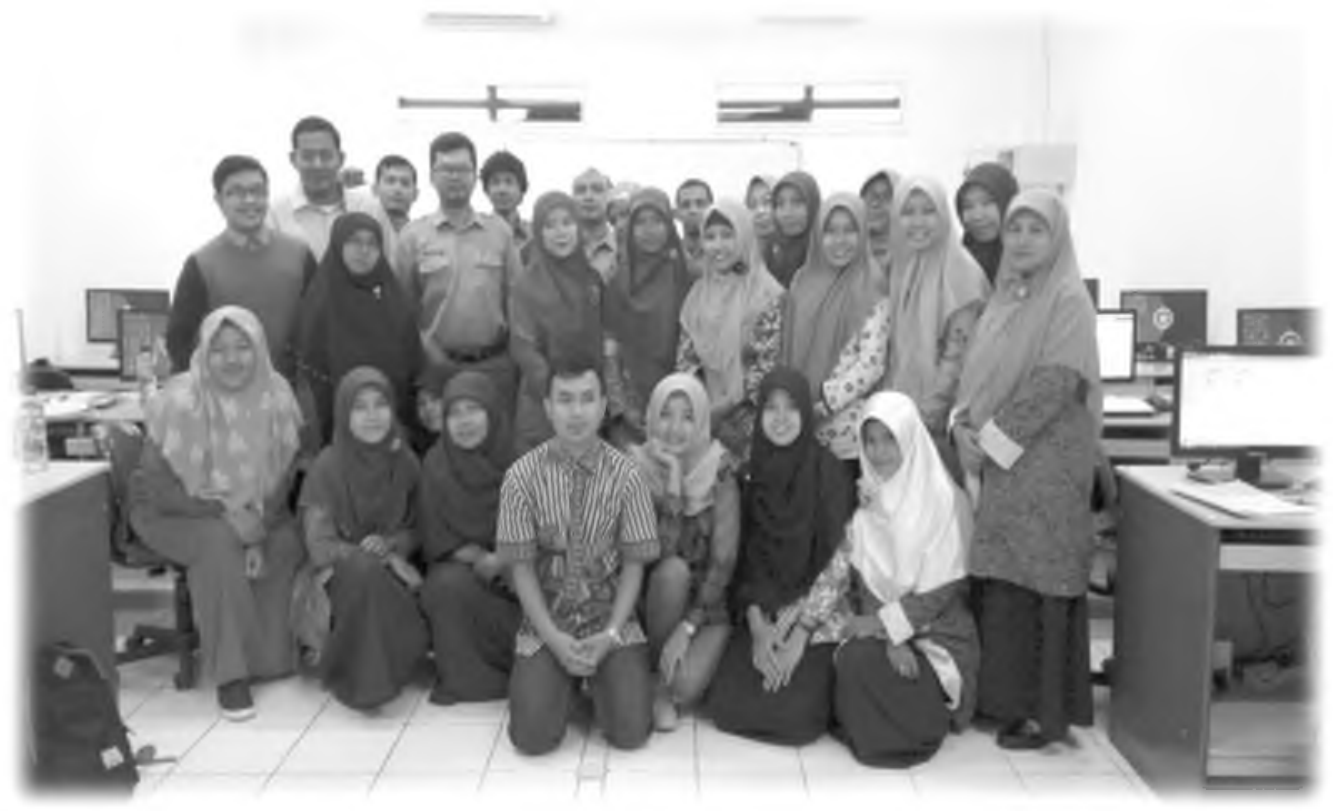

Gambar 1. Guru-guru SD IT Salsabila Al-Muthi'in peserta pendampingan beserta Dosen-dosen pendamping hari ke-2.

2. Meningkatnya kompetensi bagi guru dalam pembuatan bahan ajar berbasis multimedia. Contoh bahan ajar berbasis multimedia yang dibuat oleh guru setelah pengabdian kepada masyarakat.
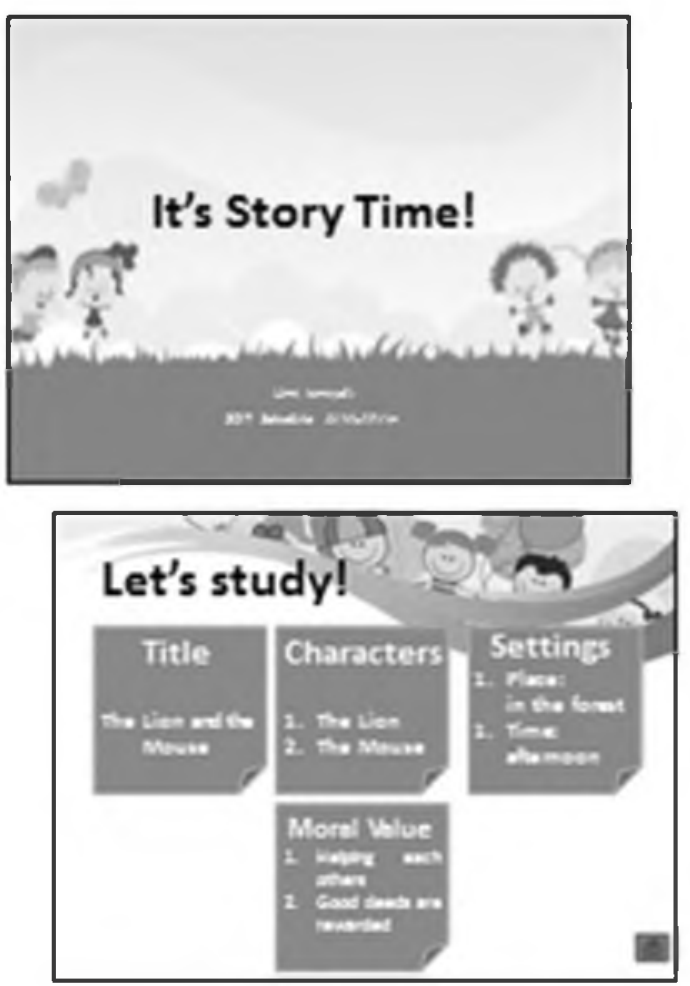
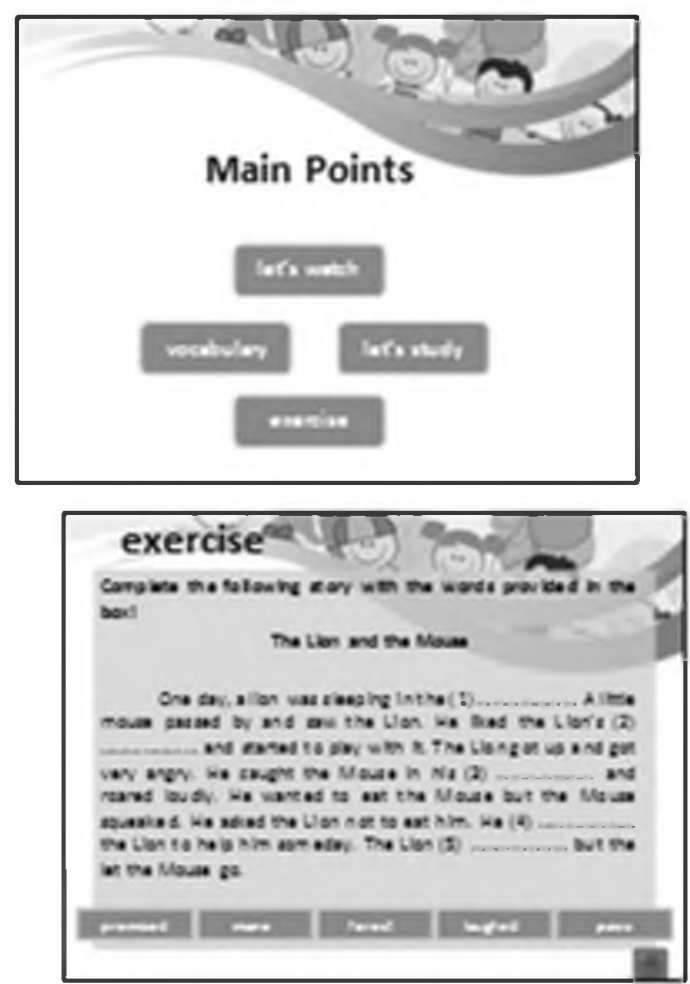

Gambar 2. Contoh bahan ajar bahasa inggris berbasis multimedia 

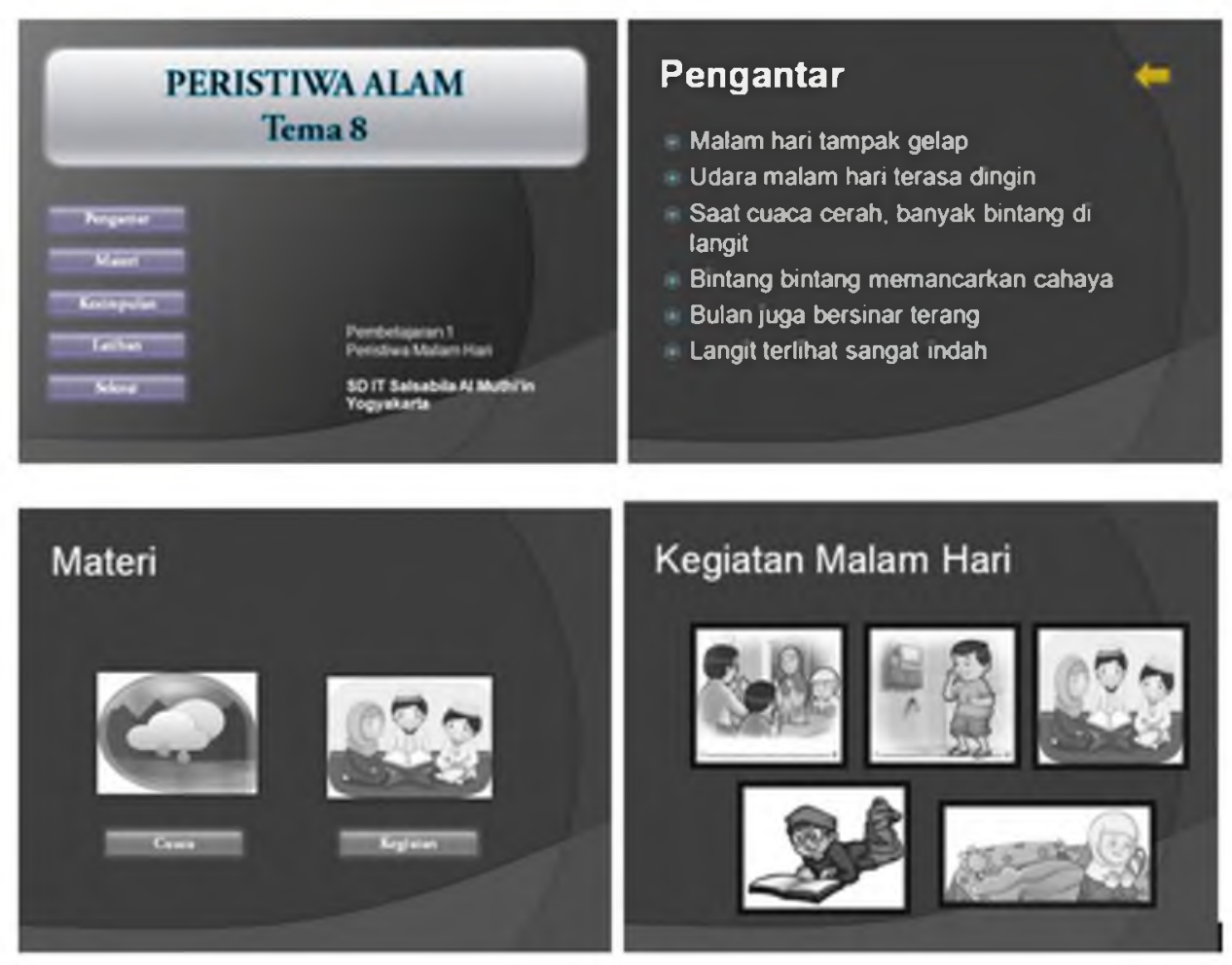

Gambar 3. Contoh bahan ajar tematik berbasis multimedia

\section{Kesimpulan}

Setelah dilakukan pendampingan membuat bahan ajar berbasis multimedia menggunakan perangkat lunak Macromedia Flash selama 2 hari diperoleh kesimpulan bahwa:

1. Penyelenggaraan pendampingan tentang pembuatan / pengembangan bahan ajar / diktat untuk para guru oleh instansi yang terkait, secara tidak langsung akan meningkatkan life skill guru.

2. Pendampingan dalam pembuatan bahan ajar berbasis multimedia menggunakan Macromedia Flash yang memberikan media pembelajaran berefek animasi dapat menarik minat siswa untuk memahami materi yang diajarkan.

\section{Daftar Pustaka}

[1] Anonim, 2010, Pembuatan Modul Multimedia, Edu Media Nusantara, Malang

[2] Dhany Yudhiantoro, 2006, Membuat Animasi WEB dengan Macromedia Flash Professional 8, Andi.

[3] Panduan Pelaksanaan Penelitian dan PPM Edisi X 2016, www. simlitabmas.ristekdikti.go.id, diakses pada tanggal 19 Januari 2017.

[4] Zeembry, 2006, 12 Jurus Pamungkas Animasi Kartun dengan Flash 8,. Elex media Komputindo. Jakarta. 
